\title{
Assessment of Day Time Anthesis Warming on Rice Cultivars under Varying Textured Sites of South-Western Punjab, India
}

\author{
Navjot Kaur Dhillon ${ }^{1}$, Sudhir Kumar Mishra2 ${ }^{2}$, Harinder Singh $^{3^{*}}$ \\ ${ }^{1}$ Directorate of Extension Education, PAU, Ludhiana, India \\ ${ }^{2}$ Punjab Agricultural University, Regional Research Station (RRS), Faridkot, India \\ ${ }^{3}$ Punjab Agricultural University, Farm Advisory Service Scheme (FASS), Faridkot, India \\ Email: ^harinder06@rediffmail.com
}

How to cite this paper: Dhillon, N.K., Mishra, S.K. and Singh, H. (2021) Assessment of Day Time Anthesis Warming on Rice Cultivars under Varying Textured Sites of South-Western Punjab, India. Agricultural Sciences, 12, 112-127.

https://doi.org/10.4236/as.2021.122008

Received: January 6, 2021

Accepted: February 22, 2021

Published: February 25, 2021

Copyright $\odot 2021$ by author(s) and Scientific Research Publishing Inc. This work is licensed under the Creative Commons Attribution International License (CC BY 4.0).

http://creativecommons.org/licenses/by/4.0/

\begin{abstract}
Rice production is highly influenced by the prevailing weather conditions, physico-chemical properties of the soil, the yielding potential of cultivars besides, several crop management practices and inputs. To understand the performance of the tiller production of various paddy cultivars under varying soil texture sites of the south-western Punjab, four rice cultivars viz., PR121 $\left(\mathrm{V}_{1}\right)$, PAU201 $\left(\mathrm{V}_{2}\right)$, PR128 $\left(\mathrm{V}_{3}\right)$ and PR129 $\left(\mathrm{V}_{4}\right)$ were grown at three different locations having soil texture from light to heavy. Sowing of nursery was completed between May 15, 2019 and May 23, 2019 however, seedlings were transplanted in the well prepared field during 05-20 June, 2019. Results of the present study clearly depicted the role of weather parameters on plant height, effective tillers, grain yield and spikelet sterility in the rice crop. High temperatures have detrimental effects on fertility of rice varieties, regardless the transplanting time. Among different rice cultivars, sterility was the lowest (17.8\%) in PR121 and the highest $42.6 \%$ in PR129. Apart from the varietal differences, the lowest sterility $28.4 \%$ recorded in medium textured soil was lowered by $21.5 \%$ and $27.8 \%$ than light and high textured soils. Cultivar PR121 produced 3.9\%, 7.7\% and 15\% higher grain yield than PR128, PAU201 and PR129, respectively. The response of anthesis period thermal stress on spikelet sterility should be considered to develop the temperature tolerant varieties for addressing the climate change issues.
\end{abstract}

\section{Keywords}

Rice, Soil Texture, Spikelet Sterility, Thermal Stress 


\section{Introduction}

Rice, an important crop for India and world, plays a very significant role in agrarian economy of the nation. Rice production in India has been significantly increased from 20.6 million tonnes during 1950-1951 to 116.48 million tonnes during 2018-2019. Rice production is highly influenced by the prevailing weather conditions, physico-chemical properties of the soil, yielding potential of the cultivars in addition of several crop management practices and other inputs. For rice crop, optimum temperature is $25^{\circ} \mathrm{C}-31^{\circ} \mathrm{C}$ for tiller production, $30^{\circ} \mathrm{C}-33^{\circ} \mathrm{C}$ for anthesis and $20^{\circ} \mathrm{C}-29^{\circ} \mathrm{C}$ for ripening [1]. Both low as well as high temperatures prevailing from panicle initiation to flowering stages of rice may cause the spikelet sterility in rice [2] [3] and [4]. Temperature below $18^{\circ} \mathrm{C}$ for two or more days between panicle initiation and booting stage leads to spikelet sterility [5] likewise, temperature at $35^{\circ} \mathrm{C}$ or above during flowering stage also enhances spikelet sterility [6]. Global warming is projected to be continued causing temperature to rise by $0.3^{\circ} \mathrm{C}$ to $4.8^{\circ} \mathrm{C}$ at the end of this century compared to baseline of 1986-2005 [7]. Any risk of the elevated temperature particularly around anthesis stage may lead the spikelet sterility through producing the higher number of the empty spikes.

Prevalence of heat stress for extended duration during reproductive phases of crop seriously deteriorate the quality of rice production [8] in similar fashion as for wheat [9] that is expected to further aggravate under changing climatic conditions [10]. Because, spikelet sterility is expected to become a serious problem under elevated air temperatures [11]. In future with advancement of global warming, the more frequent heat-induced spikelet sterility may cause the high instability of rice production [12]. Similarly, [13] also discussed that the heatinduced spikelet sterility in rice mainly occurs due to exposure of panicles to heat stress between booting and flowering stages. In fact, the environmental variables largely govern the crop growth and development besides affecting the rate of various physiological processes within plant body. For example, spikelet sterility begins when the daily maximum temperature reaches approximately at or above $34^{\circ} \mathrm{C}-36^{\circ} \mathrm{C}$ [14] [15] and [16]. In addition, high humidity also promotes spikelet sterility [16] and [6]. Similarly, low humidity [13], wind [6], and high $\mathrm{CO}_{2}$ concentration [6] also influence the sterility. The mechanism(s) of rice spikelet sterility caused by high temperatures includes the reduction of full development of pollen [14], faulty dehiscence of anthers [13] and [17] hence, low number of healthy pollen grains at the stigma [13]. Generally, panicles of rice plants are heat-sensitive organ hence, heat-induced spikelet sterility causes a severe decline in the fertility.

Among several environmental factors influencing the growth and yield of crops the light, temperature and moisture both in air and soil are most important. The optimum set of climatic variables for good growth of crops can be easily obtained only through altering the transplanting time for rice. Early or optimum transplanting may increase the grain yield of hybrid rice [18] and [19] but, 
late transplanting often leads to sub-optimal productivity of rice owing to the shortening of vegetative period [9]. Therefore, determination of optimum time of transplanting is crucial for hybrid rice due to its thermo-sensitivity nature over conventional inbreed high yielding cultivars [20] The objectives of this study are: 1) to study the effect of high day temperature on spikelet sterility, grain yield and yield attributes of rice cultivars at different soil textured sites, 2) to work out the level of thermal stresses during anthesis stage, 3) to optimize the transplanting dates for avoiding thermal stress at anthesis, and 4) to develop prediction model to assess the spikelet sterility.

\section{Material and Methods}

Adoptive research trials have been conducted in south-western regions of Punjab during May-October, 2019. Agro eco-situations were made on the basis of soil type. The experimental soil of different sites (Figure 1) was light, medium and heavy textured. The composition of the soil at each experimental site has

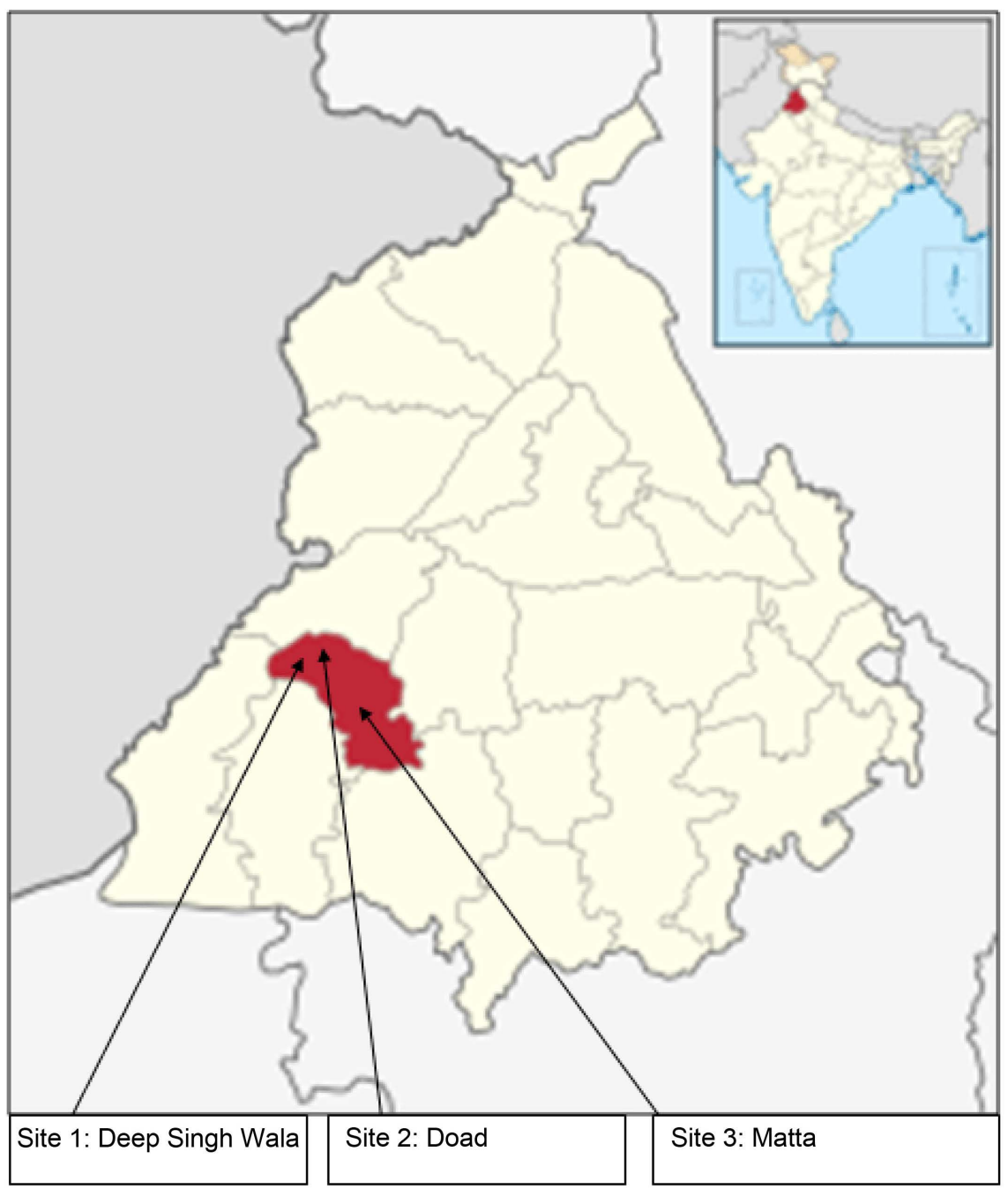

Figure 1. Location map of experimental sites. 
been presented in Table 1. Four rice varieties viz. PR121 $\left(\mathrm{V}_{1}\right)$, PAU201 $\left(\mathrm{V}_{2}\right)$, PR128 $\left(\mathrm{V}_{3}\right)$ and PR129 $\left(\mathrm{V}_{4}\right)$ were used in which $\mathrm{V}_{3}$ and $\mathrm{V}_{4}$ were new varieties. The unit plot size was 500 square meter. In a well prepared field the rice seedlings ( 25 to 30 days old) were manually transplanted at the spacing of $20 \times 15 \mathrm{~cm}$ using two seedlings per hill from $05^{\text {th }}$ June to $20^{\text {th }}$ June. For control of broadleaf weeds Algrip (Metsulfuron) 20 WP @30 g per acre in150 litres of water was applied as post-emergence at 20 - 25 days after transplanting. Based on the rainfall and field situations, irrigation was applied. Through frequent irrigation, the water shortage was avoided throughout the crop period. Nitrogen @150 kg/ha along with the phosphorus and potassium @30 kg/ha was supplied to the crop. Before the last puddling, $1 / 3^{\text {rd }}$ dose of nitrogen and whole amount of phosphorus and potassium was applied. The remaining nitrogen was broadcasted in two splits, one at three weeks after transplanting and the second at three weeks afterwards. For the remaining cultural practices and plant protection measures, package of practices for the crops (Kharif) of Punjab (https://www.pau.edu/content/pf/pp_kharif.pdf) were followed.

Plants of one meter row length (5 hills each from three locations) were selected and marked for tiller counting while, the final plant height was measured from the soil surface to the tip of last leaf. The physiological maturity in the crop was determined when $95 \%$ of spikelets had turned from green to yellow considering that crop was ready to harvest. Similarly, the spikelet fertility/sterility were manually evaluated by squeezing the grains with index finger and thumb to determine whether the spikelet was filled or not. The filled grains were considered as fertile grains whereas, completely empty grains were termed as the sterile grains following [21].

The observed data were subjected to analysis of variance (ANOVA) for the randomized plot design using IBM SPSS for Windows 21.0 (IBM SPSS 21.0, Inc., Chicago, U.S.A.). All data sets were subjected to ANOVA and the differences between the treatment means were separated by the Duncan's Multiple Range Test (DMRT) post hoc test at $95 \%$ confidence interval. The treatment means difference at $\mathrm{p}<0.05$ were considered statistically significant. The weather data during the study period (Figure 2) revealed that ranging from $14^{\circ} \mathrm{C}$ to $32^{\circ} \mathrm{C}$ and $26^{\circ} \mathrm{C}$ to $45^{\circ} \mathrm{C}$ mean of minimum and maximum temperature for the crop season

Table 1. Soil composition of different experimental sites.

\begin{tabular}{cccc}
\hline & \multicolumn{3}{c}{ Experimental sites } \\
\cline { 2 - 4 } Parameters & $\begin{array}{c}\text { Site 1: Light } \\
\text { texture }\end{array}$ & $\begin{array}{c}\text { Site 2: Medium } \\
\text { texture }\end{array}$ & $\begin{array}{c}\text { Site 3: Heavy } \\
\text { texture }\end{array}$ \\
\hline Sand (\%) & 72 & 38 & 16 \\
Silt (\%) & 14 & 44 & 32 \\
Clay (\%) & 14 & 18 & 52 \\
Organic carbon (\%) & 0.39 & 0.48 & 0.61 \\
\hline
\end{tabular}


were $25^{\circ} \mathrm{C}$ and $34^{\circ} \mathrm{C}$, respectively. Similarly, diurnal mean of the relative humidity held between $24 \%$ and $88 \%$ having $65 \%$ as seasonal average. Total rainfall 284 $\mathrm{mm}$ has been recorded during the crop season. The daily maximum temperature during flowering stage was averaged to work out the level of heat/thermal stress with varying intensities, describe as under:

\begin{tabular}{ccc}
\hline Sr. No & Stress level & Category \\
\hline 1 & Days $>33^{\circ} \mathrm{C}$ & Moderate \\
2 & Days $>34^{\circ} \mathrm{C}$ & High \\
3 & Days $>35^{\circ} \mathrm{C}$ & Severe \\
4 & Days $>36^{\circ} \mathrm{C}$ & Extreme \\
5 & Days $>37^{\circ} \mathrm{C}$ & Extremely high \\
\hline
\end{tabular}

In addition, correlation coefficient was done to establish the relationship between levels of thermal stress and the spikelet sterility. Besides, the regression equations were developed to forecast the spikelet sterility of rice under varying transplanting environments.

\section{Results}

\subsection{Variations in the Minimum and Maximum Temperature}

The lowest minimum temperature held between $19.2^{\circ} \mathrm{C}$ and $22.4^{\circ} \mathrm{C}$ during two

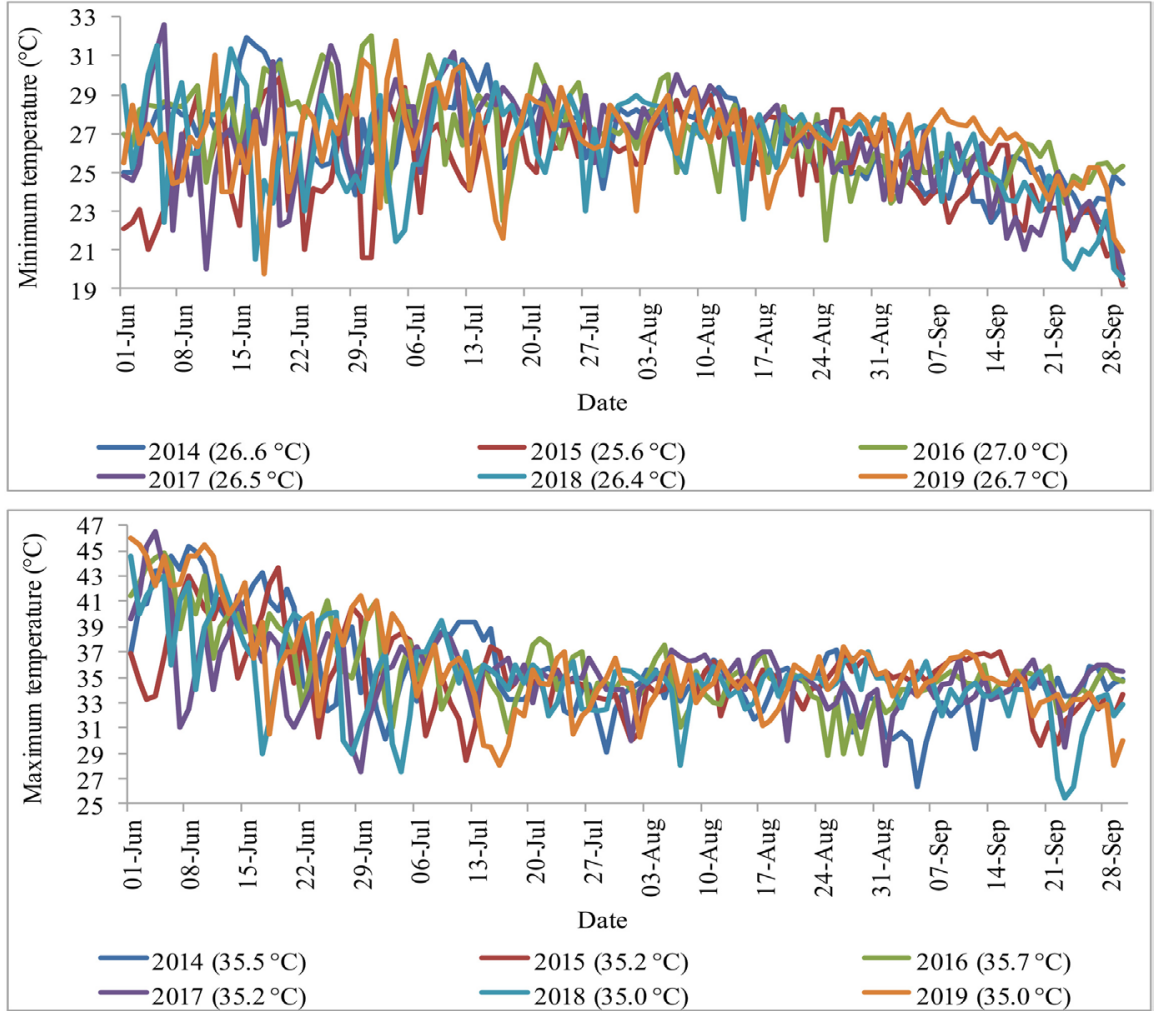

Figure 2. Minimum and maximum temperature during crop growth period. 
consequtive years 2015 and 2014 , respectively. While with $32.0^{\circ} \mathrm{C}$ and $32.6^{\circ} \mathrm{C}$, years 2016 and 2017 recorded the highest (Figure 2). In different years the lowest range of the maximum temperature $\left(25.5^{\circ} \mathrm{C}-44.5^{\circ} \mathrm{C}\right)$ was recorded during the year 2018 whereas, the highest maximum temperature was $46.6^{\circ} \mathrm{C}$ during 2017 followed by $46.0^{\circ} \mathrm{C}$ during 2019 . Ranging from $25.6^{\circ} \mathrm{C}$ during 2015 to $27.0^{\circ} \mathrm{C}$ during 2016 , the crop season minimum temperature was $26.6^{\circ} \mathrm{C}, 26.5^{\circ} \mathrm{C}, 26.4^{\circ} \mathrm{C}$ and $26.7^{\circ} \mathrm{C}$ during the year 2014, 2017, 2018 and 2019, respectively. Besides the huge diurnal variations, the mean maximum temperature during crop season was between 35.0 (year 2018 and 2019) and $35.7^{\circ} \mathrm{C}$ (year 2016), respectively. But, it was $35.2^{\circ} \mathrm{C}$ (during 2015 and 2017) and $35.5^{\circ} \mathrm{C}$ during 2014 (Figure 2).

\subsection{Grain Yield}

Among cultivars, significant differences were observed in grain yield at different soil textured sites. Grain yield ranged from 57.69 to $69.7 \mathrm{q} / \mathrm{ha}$ in light, 62 to 73 $\mathrm{q} /$ ha in medium and 62 to $73.4 \mathrm{q} /$ ha in heavy textured soil. Cultivar PR121 significantly produced the highest yield on medium to heavy soils, being at par with PR128 on medium textured soil. Average grain yield across the soil textured sites was remarkably higher in PR121 and showed superiority of 3.9\%, 7.7\% and 15\% over PR128, PAU201 and PR129, respectively. Regarding cultivars better translocation and partitioning of assimilates to grain may be the cause of higher yield (Table 2).

\subsection{Yield Attributes}

Various yield attributing characters were significant effects of different soil texture sites, cultivars on panicle length (Table 2 ). The panicle length (cm) was significantly decreased in light texture soil whereas, the highest was observed in medium texture soils. Among varieties, the variety PR129 produced lengthily panicles being identical with PR128 whereas, shorter panicles were recorded in

Table 2. Yield and yield attributes of rice cultivars in different soil textures.

\begin{tabular}{|c|c|c|c|c|c|c|c|c|c|c|c|c|}
\hline \multirow[t]{2}{*}{ Parameter } & \multicolumn{4}{|c|}{$\begin{array}{l}\text { Location-I } \\
\text { (Light texture soil) }\end{array}$} & \multicolumn{4}{|c|}{$\begin{array}{c}\text { Location-II } \\
\text { (Medium texture soil) }\end{array}$} & \multicolumn{4}{|c|}{$\begin{array}{c}\text { Location-III } \\
\text { (Heavy texture soil) }\end{array}$} \\
\hline & PR128 & PAU201 & PR129 & PR121 & PR128 & PAU201 & PR129 & PR121 & PR128 & PAU201 & PR129 & PR121 \\
\hline Panicle length $(\mathrm{cm})$ & $22.9 b$ & $24.6 c$ & $25.0 \mathrm{c}$ & $20.8 \mathrm{a}$ & $27.3 \mathrm{~b}$ & $26.3 b$ & $26.8 \mathrm{~b}$ & $21.6 a$ & $25.1 \mathrm{c}$ & $23.5 b$ & $25.7 \mathrm{c}$ & $20.6 \mathrm{a}$ \\
\hline Grains/panicle & $74.3 \mathrm{a}$ & $102.0 \mathrm{c}$ & $83.5 b$ & $75.4 \mathrm{a}$ & $102.0 \mathrm{c}$ & $98.1 \mathrm{~b}$ & $87.7 \mathrm{a}$ & $86.9 \mathrm{a}$ & $88.0 \mathrm{~b}$ & $63.55 \mathrm{a}$ & $67.1 \mathrm{a}$ & $81.8 \mathrm{~b}$ \\
\hline Sterility (\%) & $44.6 \mathrm{c}$ & $30.6 b$ & $43.4 \mathrm{c}$ & $19.3 \mathrm{a}$ & $31.6 \mathrm{c}$ & $28.9 b$ & $36.6 \mathrm{~d}$ & $16.5 \mathrm{a}$ & $38.8 b$ & $41.1 \mathrm{~b}$ & $47.7 \mathrm{c}$ & $17.5 \mathrm{a}$ \\
\hline 1000-grain weight $(\mathrm{g})$ & $28.7 \mathrm{bc}$ & $24.4 \mathrm{a}$ & $29.4 c$ & $27.2 b$ & $30.6 a$ & $30.3 \mathrm{a}$ & $31.1 b$ & $32.0 \mathrm{~b}$ & $30.9 a$ & $35.6 \mathrm{c}$ & $33.1 b$ & $32.2 \mathrm{~b}$ \\
\hline Effective tillers (no./hill) & $9.8 \mathrm{a}$ & $9.0 \mathrm{a}$ & $8.6 a$ & $13.8 \mathrm{~b}$ & $10.8 \mathrm{~b}$ & $9.4 \mathrm{a}$ & $11.2 \mathrm{~b}$ & $14.2 \mathrm{c}$ & $10.2 \mathrm{ab}$ & $9.6 \mathrm{a}$ & $9.4 \mathrm{a}$ & $12.8 \mathrm{~b}$ \\
\hline Plant height $(\mathrm{cm})$ & $110.4 \mathrm{~b}$ & $106.0 \mathrm{a}$ & $120.8 \mathrm{c}$ & $104.6 \mathrm{a}$ & $125.6 \mathrm{c}$ & $114.4 \mathrm{~b}$ & $116.0 \mathrm{~b}$ & $103.6 \mathrm{a}$ & $127.2 \mathrm{~b}$ & $115.8 \mathrm{a}$ & $128.8 \mathrm{~b}$ & $111.0 \mathrm{a}$ \\
\hline
\end{tabular}

Mean values (for different variables) within a column with different alphabets are significantly different by Duncan's Multiple Range Test at $p<0.05$. 
variety PR121. This may be due to poor health status of light texture soil along with other soil physical conditions. Among varieties, lengthily panicles may be due to better genetic expression.

Large number of panicle size was observed among the cultivars and least was recorded at different soil texture sites. All cultivars had intermediate to heavy panicle size ranging from 98 to 142 spikelets per panicle. Heavy texture soil produced significantly less spikelets/panicle (119) in comparison to medium texture (132) and low textured soil (130). The new cultivars PR128 and PR129 consistently produced panicles of larger size than remaining variety. Medium textured soil exhibited more number of grains/panicle (93) followed by light (83) and heavy (75) textured soil. Among cultivars PR128 and PAU201 were more efficient in producing more grains/panicle.

Medium texture soil was relatively superior for producing more number of effective tillers/hill (10.9) closely followed by heavy texture (10.7) and light texture (9.6) soil. Among cultivar PR121 produced maximum effective tillers (11.7/hill) whereas, PR128 and PR129 were identical (10.3/hill) and least (9.3/hill) have been recorded in PAU201. Similarly, plant height varied among the rice cultivars at different textured sits. The average plant height at maturity ranged from $106.4 \mathrm{~cm}$ (in PR121) to $121.8 \mathrm{~cm}$ (in PR129). Heavy textured soils recorded remarkably taller plants $(120.7 \mathrm{~cm})$ in comparison to light textured soil $(110.4 \mathrm{~cm})$.

On average, 1000 grain weight remarkably decreased on light textured soil, whereas verities didn't show sufficient difference. It was observed that variety PR128 and PR129 being identical while, test weight was significantly higher in light textured soil, in medium textured soil. Variety PR129 and PR121 has been identical for higher test weight while, variety PAU201 had significant lead on heavy textured soil.

\subsection{Spikelet Sterility}

In future climates, greater heat tolerant capacity around anthesis will be required in rice. There was significant variation in spikelet sterility in rice varieties. All cultivars had shown response to higher temperature at anthesis resulting $17 \%$ $42 \%$ spikelet sterility. Variety PR121 significantly showed high resistance to temperature. Whereas new cultivars PR129 and PR128 were more susceptible to temperature showing $42 \%$ to $37 \%$ spikelet sterility, respectively. Medium textured soil produced $27 \%$ spikelet sterility being minimum among the sites.

\subsection{Level of Thermal Stresses during Rice Flowering}

The rice crop experienced varying level of sterility under different trans-planting environments. The early transplanting (June 05) recorded maximum duration of $11.2,8.7$ and 4.0 days, respectively under moderate (days $>33^{\circ} \mathrm{C}$ ), high (days $>$ $34^{\circ} \mathrm{C}$ ) and extreme (days $>35^{\circ} \mathrm{C}$ ) level of thermal stresses. The rice transplanted on June 10 faced minimum duration of 8.8 and 6.2 days under moderate and 
high thermal stress levels, respectively. But, as transplanting was delayed up to June 15 and June 20, these moderate and high stresses again increased by 0.7 days in each from June 10 transplanting, respectively. The extreme stress level was found to be decreased with each delay in rice transplanting. Similarly, level of extremely high stress (days $>36^{\circ} \mathrm{C}$ ) was maximum (2.2 days) under June 10 , followed by 2.0 days in June 15, 1.2 days in June 05 and 1.0 days in June 20 transplanting (Figure 3). All the thermal levels followed second order polynomial trends, except the severe stress level that followed the linear trend. The coefficient of determination between $\mathrm{R}^{2}=0.86$ and 0.99 showed a high level of significance in the trends of stress levels. Despite from the varietal differences, lowest sterility in medium textured soils (28.4\%) was lowered by $21.5 \%$ in light and $27.8 \%$ in high textured soil. These results are evident for the adequacy of the medium texture soils for attainment of higher level of fertility in rice, in comparison of the light and the heavy textured soils. Among different rice cultivars, sterility was lowest (17.8\%) in PR121 and highest (42.6\%) in PR129. The critical evaluation of Figure 3 clearly depicted that cultivar PR 121 produced lower sterility by 2.39, 2.16 and 1.89 times than in PR129, PR128 and PAU201, respectively.

Under different transplanting dates, the duration of the moderate thermal stress was 11 - 12 days in June 05, 9 - 12 days in June 10, 6 - 9 days in June 15 and 1 - 5 days in June 20 transplanting. The highest stress period existed for 9 12 days, 6 - 9 days and 3 - 4 days under high, severe and extreme category. Notably during 2014 and 2019 , extremely high stress (day $>37^{\circ} \mathrm{C}$ ) has been also appeared for a single day, both years (Table 3).

\subsection{Correlation Coefficient between Rice Sterility and Thermal Stress}

The correlation coefficient between rice sterility and level of thermal stress days (Table 4) revealed that the spikelet sterility in both the early (June 05) and late (June 20) transplanted rice was negatively influenced by the level of thermal

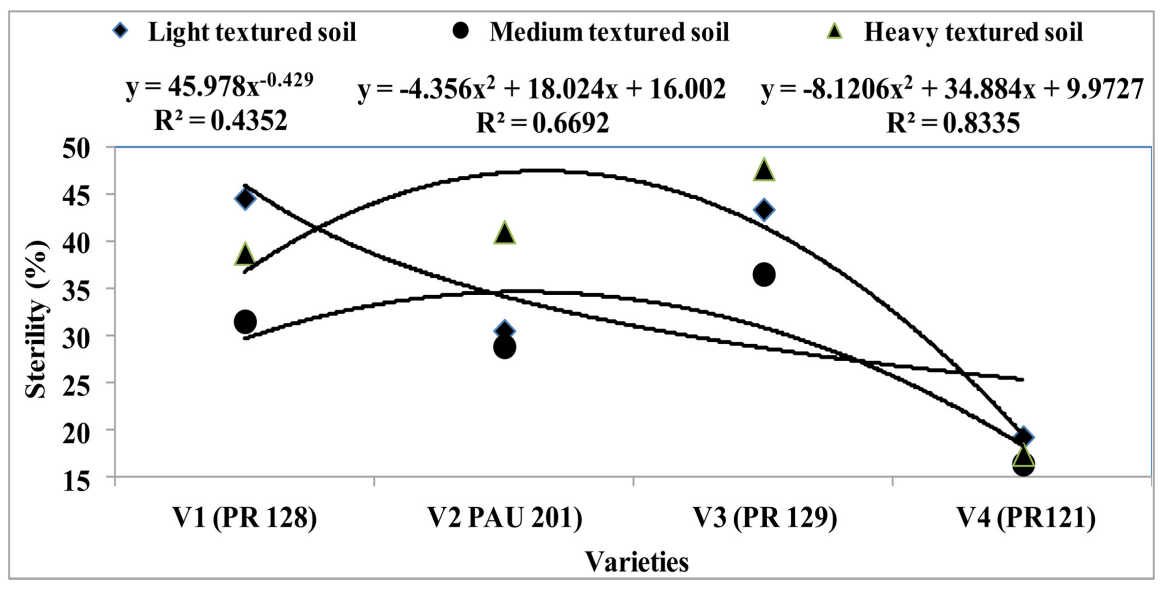

Figure 3. Sterility percentage in rice cultivars at different soil textured sites. 
N. K. Dhillon et al.

Table 3. Patterns of thermal stress levels during flowering of rice at different transplanting dates from 2014 to 2019.

\begin{tabular}{|c|c|c|c|c|c|c|}
\hline & Days $>33^{\circ} \mathrm{C}$ & Days $>34^{\circ} \mathrm{C}$ & Days $>35^{\circ} \mathrm{C}$ & Days $>36^{\circ} \mathrm{C}$ & Days $>37^{\circ} \mathrm{C}$ & Total \\
\hline \multicolumn{7}{|c|}{ Transplanting: June 05, Flowering: Aug 12 to Aug 24} \\
\hline 2014 & 11 & 9 & 5 & 1 & 0 & 26 \\
\hline 2015 & 12 & 10 & 2 & 0 & 0 & 24 \\
\hline 2016 & 12 & 10 & 4 & 1 & 0 & 27 \\
\hline 2017 & 11 & 9 & 7 & 4 & 0 & 31 \\
\hline 2018 & 11 & 7 & 3 & 0 & 0 & 21 \\
\hline 2019 & 10 & 7 & 3 & 1 & 0 & 21 \\
\hline Mean & 11.2 & 8.7 & 4.0 & 1.2 & 0.0 & 25 \\
\hline \multicolumn{7}{|c|}{ Transplanting: June 10, Flowering: Aug 22 to Sep 02} \\
\hline 2014 & 7 & 5 & 4 & 2 & 1 & 19 \\
\hline 2015 & 12 & 12 & 7 & 3 & 0 & 34 \\
\hline 2016 & 5 & 0 & 0 & 0 & 0 & 5 \\
\hline 2017 & 6 & 2 & 0 & 0 & 0 & 8 \\
\hline 2018 & 11 & 8 & 3 & 3 & 0 & 25 \\
\hline 2019 & 12 & 10 & 7 & 5 & 1 & 35 \\
\hline Mean & 8.8 & 6.2 & 3.5 & 2.2 & 0.3 & 21 \\
\hline \multicolumn{7}{|c|}{ Transplanting: June 15, Flowering: Sep 1 to Sep 12} \\
\hline 2014 & 2 & 0 & 0 & 0 & 0 & 2 \\
\hline 2015 & 12 & 12 & 9 & 5 & 0 & 38 \\
\hline 2016 & 11 & 7 & 2 & 0 & 0 & 20 \\
\hline 2017 & 9 & 5 & 1 & 1 & 0 & 16 \\
\hline 2018 & 9 & 4 & 1 & 1 & 0 & 15 \\
\hline 2019 & 12 & 10 & 6 & 5 & 0 & 33 \\
\hline Mean & 9.2 & 6.3 & 3.2 & 2.0 & 0.0 & 21 \\
\hline \multicolumn{7}{|c|}{ Transplanting: June 20, Flowering: Sep 11 to Sep 22} \\
\hline 2014 & 11 & 5 & 2 & 0 & 0 & 18 \\
\hline 2015 & 7 & 7 & 6 & 4 & 0 & 24 \\
\hline 2016 & 10 & 9 & 6 & 0 & 0 & 25 \\
\hline 2017 & 11 & 6 & 2 & 1 & 0 & 20 \\
\hline 2018 & 9 & 3 & 1 & 0 & 0 & 13 \\
\hline 2019 & 9 & 7 & 2 & 1 & 0 & 19 \\
\hline Mean & 9.5 & 6.2 & 3.2 & 1.0 & 0.0 & 20 \\
\hline
\end{tabular}

Table 4. Correlation coefficient between rice sterility and level of thermal stress days.

\begin{tabular}{cccccc}
\hline Transplanting time & Days $>33^{\circ} \mathrm{C}$ & Days $>34^{\circ} \mathrm{C}$ & Days $>35^{\circ} \mathrm{C}$ & Days $>36^{\circ} \mathrm{C}$ & Days $>37^{\circ} \mathrm{C}$ \\
\hline 05 June & 0.45 & 0.56 & 0.71 & 0.72 & 0.96 \\
10 June & 0.91 & 0.92 & 0.91 & 0.86 & 0.33 \\
15 June & 0.36 & 0.53 & 0.69 & 0.49 \\
20 June & 0.22 & 0.25 & 0.19 & 0.49 \\
\hline
\end{tabular}


stresses (June 05: $\mathrm{r}=-0.45$ to -0.71 and June $20: \mathrm{r}=-0.19$ to -0.72 ) though, sterility in the late transplanting was increased with the occurrence of the thermal stress towards extreme category. Whereas, the sterility in the rice spikelet was simultaneously increased with the varying intensities of thermal stresses during crop flowering. Because, rice transplanting between June 10 and June 15 may experience extreme temperature episodes during flowering stage resulting more spikelet sterility. Therefore, shifting of transplanting before or after these dates may be an option to save the crop from thermal stresses.

\subsection{Development of Sterility Prediction Model}

The heat stress induced spikelet sterility of rice under different transplanting dates may be successfully predicted using the statistical model based on the thermal stress days. Early transplanting rice sterility could be fairly predicted by using severe thermal stress (Days $>35^{\circ} \mathrm{C}$ ) based model $(\mathrm{Y}=-0.9375 \mathrm{X}+41.75$, $\mathrm{R}^{2}=0.50$ ). Similarly under optimum (June 10) transplanting time, all the stress based model may be used for sterility estimation whereas, for moderate stress based model $\left(\mathrm{Y}=0.7279 \mathrm{X}+31.57, \mathrm{R}^{2}=0.96\right)$ was the best. Model, $\mathrm{Y}=0.8571 \mathrm{X}+$ $36.29, \mathrm{R}^{2}=0.73$ based on extreme stress and $\mathrm{Y}=-1.1304 \mathrm{X}+48.74, \mathrm{R}^{2}=0.52$ based on moderate stress have been appeared as the best model for delayed and late transplanted rice sterility (Table 5).

\section{Discussion}

Rice is extremely sensitive to heat stress. Therefore, high temperatures adversely affect the rice production [22]. In future the global mean temperature is expected to increase by $>1.5^{\circ} \mathrm{C}$ by the end of the $21^{\text {st }}$ century. It is estimated that rising temperatures may reduce the production of rice by $41 \%$ at the end of the $21^{\text {st }}$ century. During 2071-2100, annual maximum temperature of Ludhiana, Punjab may be higher by $5.8^{\circ} \mathrm{C}, 5.4^{\circ} \mathrm{C}$ and $3.1^{\circ} \mathrm{C}$ in the $\mathrm{A} 1 \mathrm{~B}, \mathrm{~A} 2$ and $\mathrm{B} 2$ scenario than the baseline temperature $\left(29.8^{\circ} \mathrm{C}\right)$ whereas, winter rainfall could be deficit by $78 \%$ and $30 \%$ under the $\mathrm{A} 2$ and $\mathrm{B} 2$ scenarios, respectively [23].

Heat stress is an increase in temperature above a threshold level for a certain period that causes irreversible damage to the growth and development of plants [24]. Under future scenarios of projected warming, above critical threshold $\left(>33^{\circ} \mathrm{C}\right)$ high temperature extremes at flowering stage will be more frequent

Table 5. Forewarning model for sterility in rice caused by level of thermal stress.

\begin{tabular}{|c|c|c|c|c|c|c|c|c|}
\hline & \multicolumn{2}{|l|}{ 05-Jun } & \multicolumn{2}{|l|}{ 10-Jun } & \multicolumn{2}{|l|}{ 15-Jun } & \multicolumn{2}{|l|}{ 20-Jun } \\
\hline & Equation & $\mathrm{R}^{2}$ & Equation & $\mathrm{R}^{2}$ & Equation & $\mathrm{R}^{2}$ & Equation & $\mathrm{R}^{2}$ \\
\hline Days $>33^{\circ} \mathrm{C}$ & $\mathrm{Y}=-1.4118 \mathrm{X}+53.77$ & 0.20 & $\mathrm{Y}=0.7279 \mathrm{X}+31.57$ & 0.96 & $Y=0.2259 X+35.93$ & 0.13 & $\mathrm{Y}=-1.1304 \mathrm{X}+48.74$ & 0.52 \\
\hline Days $>34^{\circ} \mathrm{C}$ & $Y=-0.9643 X+46.36$ & 0.31 & $\mathrm{Y}=0.487 \mathrm{X}+35.0$ & 0.92 & $Y=0.2893 X+36.17$ & 0.28 & $Y=-0.288 X+39.78$ & 0.06 \\
\hline Days $>35^{\circ} \mathrm{C}$ & $Y=-0.9375 X+41.75$ & 0.50 & $Y=0.6869 X+35.56$ & 0.83 & $Y=0.4615 X+36.54$ & 0.48 & $Y=-0.2013 X+38.64$ & 0.04 \\
\hline Days $>36^{\circ} \mathrm{C}$ & $\mathrm{Y}=-0.8308 \mathrm{X}+38.97$ & 0.27 & $\mathrm{Y}=1.1681 \mathrm{X}+35.47$ & 0.92 & $\mathrm{Y}=0.8571 \mathrm{X}+36.29$ & 0.73 & $\mathrm{Y}=0.75 \mathrm{X}+37.25$ & 0.24 \\
\hline
\end{tabular}


[25] [26] and [27] across different major rice growing regions. These warming seasons are likely to negatively affect the growth, development and yield of rice crops besides some physiological aberrations. To overcome such heat stress, rice plants itself possess through different tolerance mechanisms such as transpiration cooling [28]. Increasing the spikelets per panicle is an effective approach to improve rice yield [29] and [30]. Because, rice cultivars with larger panicle often show larger sink size thus, have higher yield potential than conventional cultivars [31] and [32]. In this context, [33] reported a negative correlation between the number of spikelets per panicle and the filled-grain percentage.

Average attainable yield of these rice cultivars in Punjab is $7-7.5 \mathrm{t} / \mathrm{ha}$ (Package of practices for the crops of Punjab, Kharif2020,

https://www.pau.edu/content/pf/pp_kharif.pdf). The accumulation of pre-floral photosynthate determines reproductive sink capacity [34] while, ratio of spikelet number to tiller dry weight after spikelet differentiation was well correlated with the rice yield [35]. Considerable variation in grain yield was observed among cultivars in the study, suggesting that it is possible to further improve the attainable yield of rice. The spikelet sterility data (Table 2) revealed that in cultivar PR 121 the spikelet sterility was only 17\%, being minimum among cultivars thus, showed lower thermal stress at anthesis. Such type of genotypes may be exploited for future breeding program to develop high day temperature tolerant varieties. Similarly, [21] and [36] also reported that the levels of thermal stresses reduce the grain yield losses mainly through the spikelet sterility and reduced grain weight.

The soil texture or structure can immensely affect the crop production by altering the root growth system because growth of the roots in a same cultivar may considerably vary with soil texture [37]. The panicle length was affected by different soil texture sites and was significantly decreased in the light soil. It may be due to less fertility status of light textured soil than other soil physical conditions. Among cultivars shorter panicle was recorded in PR121. All the cultivars had intermediate to heavy panicle size ranging from 98 to 142 spikelets per panicle. The cultivars PR128 and PR129 consistently produced panicles of large size than PR121 that would be a prime factor for high yield in PR128 and PR129. Likewise, [38] has already explained that the rice cultivars having heavy panicle size attains high yield potential that may be an appropriate measure for developing new high-yielding varieties. Again, cultivar PR121 produced maximum effective tillers (11.7/hill) whereas PR128 and PR129, were identical (10.3/hill). Similarly, [39] also reported that cultivars with larger panicle produced fewer tillers than the cultivars with smaller panicles. When comparing the results of four cultivars at different textured soils, it was determined that cultivars presented high genetic variability in yield. Cultivar P 121 showed superiority over other cultivars across the soil textures. The better translocation and partitioning of assimilates towards grains may be the cause of higher yield.

Different cultivars showed differential responses against higher temperature. 
PR121 showed relatively high resistance to temperature than other cultivars. The cultivar PR129 and PR128 was more susceptible to temperature recorded $42 \%$ to $37 \%$ spikelet sterility, respectively. One hour at a spikelet tissue temperature of $\geq 33.7^{\circ} \mathrm{C}$ was sufficient to cause sterility and this coincided with anthesis stage [13]. At anthesis stage, even a shorter episode $\left(>35^{\circ} \mathrm{C}\right.$ for $\left.\geq 1 \mathrm{~h}\right)$ of heat stress badly affects the spikelets [40] and [41] while, $>38^{\circ} \mathrm{C}$ for $\geq 1$ temperatures after anthesis have minimal impact on it [42] and [43].

Although heat stress primarily affects anther dehiscence [15] [44] and [21], it is possible that in susceptible cultivar such as PR129, PR128 and PAU201 a number of other processes like, pollen swelling, another pore size is affected before fertilization [45], and pollen stickmens may also affect the growth [46]. The magnitude of sterility in a number of genotypes is related to the low content of non structural carbohydrate in panicle tissues at the meiotic stage [47]. The panicle length was affected by soil texture sites and was significantly decreased in the light textured soil. Among cultivars shorter panicle in PR121 may be due inherent genetic the cultivar characters. The lowest plant height was in PR121 $(106.4 \mathrm{~cm})$ and maximum in PR129 $(121.8 \mathrm{~cm})$. Cultivars with large panicle also have greater plant height [48]. Heavy textured soil recorded remarkably taller plants mainly because of better soil fertility status than low textured soils.

\section{Conclusion}

High temperature has a positive effect on spikelet sterility rate of rice varieties. Though, impacts of high temperature on grain weights of different rice varieties are diversified. High temperatures have detrimental effects for rice fertility. Under different transplanting dates, stress period was 9 - 12 days, 6 - 9 days and 3 4 days under high, severe and extreme category. Extremely high stress (day $>$ $37^{\circ} \mathrm{C}$ ) was also recorded for a single day, during 2014 and 2019. Among different rice cultivars, sterility was the lowest (17.8\%) in PR121 and the highest (42.6\%) in PR129. The higher grain yield in PR121 showed superiority of 3.9\%, 7.7\% and 15\% over PR128, PAU201 and PR129, respectively. Besides with minimum spikelet sterility of $17 \%$, cultivar PR121 showed lower thermal stress at anthesis and described that such type of genotypes may be encouraged to develop the temperature tolerant varieties. The developed regression model may be useful for better understanding and advance estimation of the occurrence of the thermal stress in rice crop under various soil textures and planting environments.

\section{Conflicts of Interest}

The authors declare no conflicts of interest regarding the publication of this paper.

\section{References}

[1] Yoshida, S. (1981) Fundamentals of Rice Crop Science. International Rice Research Institute, LosBaños, 48-269. 
[2] Zhong, G.R. (1991) Advance in Research on Cold Tolerance in Rice. Jiangsu Journal of Agricultural Sciences, 7, 52-56.

[3] Nahar, K., Hasanuzzaman, M. and Majumder, R.R. (2009) Effect of Low Temperature Stress in Transplanted Aman Rice Cultivars Mediated by Different Transplanting Dates. Academic Journal of Plant Sciences, 2, 132-138.

[4] Shelley, I.J., Takahashi-Nosaka, M., Kano-Nakata, M., Haque, M.S. and Inukai, Y. (2016) Rice Cultivation in Bangladesh: Present Scenario, Problems and Prospects. J. Intl. Agric. Dev, 14, 20-29.

[5] Amin, A.K.M.R. (2004) Effect of Cold Temperature and Agronomic Management on the Spikelet Sterility and Yield of Boro Rice. Ph.D. Thesis, Bangladesh Agricultural University, Mymensingh.

[6] Matsui, T., Omasa, K. and Horie, T. (1997) High Temperature-Induced Spikelet sterility of Japonica Rice at Fowering in Relation to Air Temperature, Humidity and Wind Velocity Conditions. Japanese Journal of Crop Science, 66, 449-455. https://doi.org/10.1626/jcs.66.449

[7] Stocker, T.F., Qin, D., Plattner, G.-K., Alexander, L.V., Allen, S.K. and Bindoff, N.L. (2013) Technical Summary In: Stocker, T.F., Qin, D., Plattner, G.-K., Tignor, M., Allen, S.K., Boschung, J., Nauels, A., Xia, Y., et al., Eds., Climate Change 2013: The Physical Science Basis. Cambridge University Press, Cambridge, New York.

[8] Hakata, M., Kuroda, M., Miyashita, T., Yamaguchi, T., Kojima, M., Sakakibara, H., Mitsui, T. and Yamakawa, H. (2012) Suppression of $\alpha$-Amylase Genes Improves Quality of Rice Grain Ripened under High Temperature. Plant Biotechnology Journal, 10, 1110-1117. https://doi.org/10.1111/j.1467-7652.2012.00741.x

[9] Mishra, S.K., Shekh, A.M., Pandey, V., Yadav, S.B. and Patel, H.R. (2015) Sensitivity Analysis of Four Wheat Cultivars to varying Photoperiod and Temperature at Different Phenological Stages Using WOFOST Model. Journal of Agrometeorology, 17, 74-79.

[10] Morita, S., Wada, H. and Matsue, Y. (2016) Countermeasures for Heat Damage in Rice Grain Quality under Climate Change. Plant Production Science, 19, 1-11. https://doi.org/10.1080/1343943X.2015.1128114

[11] Horie, T., Matsui, T., Nakagawa, H. and Omasa, K. (1996) Effects of Elevated $\mathrm{CO}_{2}$ and Global Climate Change on Rice Yield in Japan. In: Omasa, K., Kai, K., Taoda, H., Uchijima, Z. and Yishino, M, Eds., Climate Change and Plants in East Asia, Springer-Verlag, Tokyo, 39-56. https://doi.org/10.1007/978-4-431-66899-2_4

[12] Cruz, R.V., Harasawa, H., Lal, M., Wu, S., Anokhin, Y., Punsalmaa, B., Honda, Y., Jafari, M., Li, C. and Huu Ninh, N. (2007) Climate Change 2007: Impacts, Adaptation and Vulnerability. Cambridge University Press, Cambridge, 469-506.

[13] Satake, T. and Yoshida, S. (1978) High Temperature-Induced Sterility in Indica Rices at Fowering. Japanese Journal of Crop Science, 47, 6-17. https://doi.org/10.1626/jcs.47.6

[14] Osada, A., Sasiprapa, V., Rahong, M., Dhammanuvong, S. and Chakrabndhu, H. (1973) Abnormal Occurrence of Empty Grains of Indicia Rice Plants in the Dry, Hot Season in Thailand. Proceedings of the Crop Science Society of Japan, 42, 103-109. https://doi.org/10.1626/jcs.42.103

[15] Matsui, T., Omasa, K. and Horie, T. (2001) The Difference in Sterility due to High Temperatures during the Fowering Period among Japonica-Rice Varieties. Plant Production Science, 4, 90-93. https://doi.org/10.1626/pps.4.90

[16] Weerakoon, W.M.W., Maruyama, A. and Ohba, K. (2008) Impact of Humidity on 
Temperature-Induced Grain Sterility in Rice (Oryza sativa L.). Journal of Agronomy and Crop Science, 194, 135-140. https://doi.org/10.1111/j.1439-037X.2008.00293.x

[17] Matsui, T. and Omasa, K. (2002) Rice (Oryza sativa L.) Cultivars Tolerant to High Temperature at Fowering Anther Characteristics. Annals of Botany, 89, 683-687. https://doi.org/10.1093/aob/mcf112

[18] Pan, X., Qu, W. and Pan, X.B. (1998) Analysis on the Main Agronomic Characters and Discussion of High Yield Breeding of Early Indica Hybrid Rice. Indian Journal of Agronomy, 43, 68-70.

[19] Om, H., Singh, O.P. and Joon, R.K. (1993) Effect of Time of Transplanting and Spacing on Basmati Rice. Haryana Journal of Agronomy, 9, 87.

[20] Nayak, B.C., Dalei, B.B. and Choudhury, B.K. (2003) Response of Hybrid Rice (Oryza sativa) to Date of Planting, Spacing and Seedling Rate during Wet Season. Indian Journal of Agronomy, 48, 172-174.

[21] Prasad, P.V.V., Boote, K.J., Allen, L.H., Sheehy, J.E. and Thomas, J.M.G. (2006) Species, Ecotype and Cultivar Differences in Spikelet Fertility and Harvest Index of Rice in Response to High Temperature Stress. Field Crops Research, 95, 398-411. https://doi.org/10.1016/j.fcr.2005.04.008

[22] Peng, S., Khush, G.S., Virk, P., Tang, Q. and Zou, Y. (2008) Progress in Ideotype Breeding to Increase Rice Yield Potential. Field Crops Research, 108, 32-38. https://doi.org/10.1016/j.fcr.2008.04.001

[23] Kaur N. and Kaur, P. (2016) Projected Climate Change under Different Scenarios in Central Region of Punjab, India. Journal of Agrometeorology, 18, 88-92.

[24] Yang, J., Peng, S., Zhang, Z., Wang, Z., Visperas, R.M. and Zhu, Q. (2002) Grain and Dry Matter Yields and Partitioning of Assimilates in Japonica/Indicia Hybrid Rice. Crop Science, 42, 766-772. https://doi.org/10.2135/cropsci2002.7660

[25] Gourdji, S.M., Sibley, A.M. and Lobell, D.B. (2013) Global Crop Exposure to Critical High Temperatures in the Reproductive Period: Historical Trends and Future Projections. Environmental Research Letters, 8, Article ID: 024041. https://doi.org/10.1088/1748-9326/8/2/024041

[26] Teixeira, E.I., Fischer, G., van Velthuizen, H., Walter, C. and Ewert, F. (2013) Global Hot-Spots of Heat Stress on Agricultural Crops Due to Climate Change. Agricultural and Forest Meteorology, 170, 206-215. https://doi.org/10.1016/j.agrformet.2011.09.002

[27] Bheemanahalli, R., Sathishraj, R., Tack, J., Nalley, L.L., Muthurajan, R. and Jagadish, K.S. (2016) Temperature Thresholds for Spikelet Sterility and Associated Warming Impacts for Sub-Tropical Rice. Agricultural and Forest Meteorology, 221, 122-130. https://doi.org/10.1016/j.agrformet.2016.02.003

[28] Julia, C.m and Dingkuhn, M. (2013) Predicting Temperature Induced Sterility of Rice Spikelets Requires Simulation of Crop-Generated Microclimate. European Journal of Agronomy, 49, 50-60. https://doi.org/10.1016/j.eja.2013.03.006

[29] Li, H., Liu, L., Wang, Z., Yang, J. and Zhang, J. (2012) Agronomic and Physiological Performance of High-Yielding Wheat and Rice in the Lower Reaches of Yangtze River of China. Field Crops Research, 133, 119-129.

https://doi.org/10.1016/j.fcr.2012.04.005

[30] Zhang, H., Chen, T.T., Liu, L.J., Wang, Z .Q., Yang, J.C. and Zhang, J.H. (2013) Performance in Grain Yield and Physiological Traits of Rice in the Yangtze River Basin of China during the Last 60 yr. Journal of Integrative Agriculture, 12, 57-66. 
https://doi.org/10.1016/S2095-3119(13)60205-1

[31] Laza, R.C., Peng, S., Akita, S. and Saka, H. (2004) Effect of Panicle Size on Grain Yield of IRRI-Released Indica Rice Cultivars in the Wet Season. Plant Production Science, 7, 271-276. https://doi.org/10.1626/pps.7.271

[32] Jiang, Y.H., Zhang, H.C., Zhao, K., Xu, J .W., Wei, H.H., Long, H.Y., Wang, W.T., Dai, Q.G., Huo, Z.Y., Xu, K., Wei, H.Y. and Guo, B.W. (2014) Difference in Yield and Its Components Characteristics of Different Type Rice Cultivars in the Lower Reaches of the Yangtze River. Chinese Journal of Rice Science, 28, 621-631. (In Chinese)

[33] Ohsumi, A., Takai, T., Ida, M., Yamamoto, T., Arai-Sanoh, Y., Yano, M., Ando, T. and Kondo, M. (2011) Evaluation of Yield Performance in Rice Near-Isogenic Lines with Increased Spikelet Number. Field Crops Research, 120, 68-75.

https://doi.org/10.1016/j.fcr.2010.08.013

[34] Endo-Higashi, N. and Izawa, T. (2011) Flowering time Genes Heading Date 1 and Early Heading Date 1 Together Control Panicle Development in Rice. Plant and Cell Physiology, 52, 1083-1094. https://doi.org/10.1093/pcp/pcr059

[35] Shiratsuchi, H., Ohdaira, Y. and Takanashi, J.I. (2007) Relationship between Dry Weight at Heading and the Number of Spikelets on Individual Rice Tillers. Plant Production Science, 10, 430-441. https://doi.org/10.1626/pps.10.430

[36] Shi, W., Muthurajan, R., Rahman, H., Selvam, J., Peng, S.B. and Zou, Y.B. (2013) Source-Sink Dynamics and Proteomic Reprogramming under Elevated Night Temperature and Their Impact on Rice Yield and Grain Quality. New Phytologist, 197, 825-837. https://doi.org/10.1111/nph.12088

[37] Dou, F., Soriano, J., Tabien, R.E. and Chen, K. (2016) Soil Texture and Cultivar Effects on Rice (Oryza sativa, L.) Grain Yield, Yield Components and Water Productivity in Three Water Regimes. PLOS ONE, 11, e0150549. https://doi.org/10.1371/journal.pone.0150549

[38] Yuan, L.P. (2012) Conceiving of Breeding Further Super-High Yield Hybrid Rice. Hybrid Rice, 77, 1-2 (In Chinese with English abstract)

[39] Khush, G.S. (1997) Origin, Dispersal, Cultivation and Variation of Rice. In: Sasaki T. and Moore, G., Eds., Oryza: From Molecule to Plant, Springer, Dordrecht, 25-34. https://doi.org/10.1007/978-94-011-5794-0_3

[40] Jagadish, S.V.K., Muthurajan, R., Oane, R., Wheeler, T.R., Heuer, S., Bennett, J. and Craufurd, P.Q. (2010) Physiological and Proteomic Approaches to Address Heat tolerance during Anthesis in Rice (Oryza sativa L.). Journal of Experimental Botany, 61, 143-156. https://doi.org/10.1093/jxb/erp289

[41] Sathishraj, R., Bheemanahalli, R., Ramachandran, M., Dingkuhn, M., Muthurajan, R. and Krishna, J.S. (2015) Capturing Heat Stress Induced Variability in Spikelet Sterility Using Panicle: Leaf and Air Temperature under Field Conditions. Field Crops Research, 190, 10-17. https://doi.org/10.1016/j.fcr.2015.10.012

[42] Yoshida, S., Satake T. and Mackill, D. (1981) High Temperature Stress. No. 67, International Rice Research Institute, LosBaños, 1-15.

[43] Jagadish, S.V.K., Craufurd, P.Q. and Wheeler, T.R. (2007) High Temperature Stress and Spikelet Fertility in Rice (Oryza sativa L.). Journal of Experimental Botany, 58, 1627-1635. https://doi.org/10.1093/jxb/erm003

[44] Matsui, T. and Kagata, H. (2003) Characteristics of Floral Organs Related to Reliable Self Pollination in Rice (Oryza sativa L.). Annals of Botany, 91, 473-477. https://doi.org/10.1093/aob/mcg045 
[45] Matsui, T., Omasa, K. and Horie, T. (2000) High Temperature at Fowering Inhibits Swelling of Pollen Grains, a Driving Force for Thecae Dehiscence in Rice (Oryza sativa L.). Plant Production Science, 3, 430-434. https://doi.org/10.1626/pps.3.430

[46] Kakani, V.G., Prasad, P.V.V., Craufurd, P.Q. and Wheeler, T.R. (2002) Response of in Vitro Pollen Germination and Pollen Tube Growth of Groundnut (Arachis hypogaea L.) Genotypes to Temperature. Plant, Cell \& Environment, 25, 1651-1661. https://doi.org/10.1046/j.1365-3040.2002.00943.x

[47] Meng, L.S., Wang, Y.B., Loake, G.J. and Jiang, J.H. (2016) Seed Embryo Development Is Regulated via an AN3-MINI3 Gene Cascade. Frontiers in Plant Science, 7, 1645. https://doi.org/10.3389/fpls.2016.01645

[48] Visperas, R.M., Peng, S., Khush, G.S. and Pamplona, A. (2000) Relative Performance of New Plant Type Lines during the Dry and Wet Seasons. Philippine Journal of Crop Science, 25, 51. 